[10] D. N. Jones, S. D. Knox, J. Chem. Soc, Chem. Commun. 1975, 165.

[11] N. Greenspoon, E. Keinan, J. Org. Chem. 1988, 53, 3723.

[12] R. O. Hutchins, K. Learn, J. Org. Chem. 1982, 47, 4380.

[13] E. Keinan, N. Greenspoon, J. Org. Chem. 1983, 48, 3545

[14] a) J. Tsuji, T. Yamakawa, Tetrahedron Lett. 1979, 631 ; b) J. Tsuji, I. Shimizu, I. Minami. Chem. Lett. 1984, 1017; c) J. Tsuji, I. Minami, I. Shimizu, Synthesis 1986. 623; d) D. Mandai, S. Suzuki, T. Murakami, M. Fujita, M. Kawada, J Tsuji, Tetrahedron Lett. 1992, 33, 2987; e) T. Mandai, T. Matsumoto, J. Tsuji, Synlett 1993, 113; f) T. Hayashi, H [wamura, Y Uozumi, Tetrahedron Lett. 1994, 35,4813

[15] a) B. M. Trost. E. Keinan. Tetrahedron Lett. 1980, 21, 2595; b) J. P. Godschalx J. K. Stille, ibid. 1980, 21, 2599; c) B. M. Trost, K. M. Pietrusiewicz, ibid. 1985 26, 4039; d) A. Gollaszewski, J. Schwartz, Organometallics 1985, 4, 417.

[16] J. A. Hirsch, Top. Stereochem. 1967. 199.

[17] W. Kitching. H. A. Olszowy, G. M. Drew, W. Adcock, J. Org. Chem. 1982, 47. 5153.

\section{Doubly Lithiated Oligosilanes: Synthesis and Structure of the First Vicinal Dilithiodisilane**}

Johannes Belzner, * Uwe Dehnert, and Dietmar Stalke*

The cleavage of silicon-silicon $\sigma$ bonds by alkali metals is a common method for the preparation of metalated silanes. This reaction, however, only proceeds satisfactorily if the silicon centers carry at least one aromatic substituent. ${ }^{[1]}$ The same is true for the reaction of cyclic silanes with alkali metals: while peralkylated cyclosilanes are reduced by alkali metals only to the stage of radical anions, ${ }^{[2]}$ aryl-substituted silacycles undergo bond cleavage to yield synthetically useful difunctional $\alpha, \omega$ dimetallio oligosilanes. The reactions of octaphenyltetrasilane and decaphenylcyclopentasilane with lithium have been studied extensively and have been used for the preparation of numerous organosilicon compounds. [3] To our knowledge, there are no reports about the analogous reactions of cyclotrisilanes with metals. This gap is now filled by the results of the reaction of the cyclotrisilane 1 with lithium metal, which yields, depending on the reaction conditions, either the 1,3-dilithiotrisilane $\mathbf{2}$ a or the 1,2-dilithiodisilane $\mathbf{3 a}$.
1

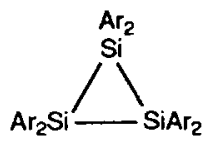<smiles></smiles>

2<smiles>[R][Si]([R])[GeH2]</smiles>

3

\section{$\mathrm{Ar}=2-\left(\mathrm{Me}_{2} \mathrm{NCH}_{2}\right) \mathrm{C}_{6} \mathrm{H}_{4}$}

2a,3a: $R=L i$

$2 b, 3 b: R=H$

The reaction of the cyclotrisilane 1 with two equivalents of lithium in 1,4-dioxane allowed the subsequent isolation of red, extremely air-sensitive crystals of $\mathbf{2 a}$, which can be smoothly protonated with cyclopentadiene to yield the trisilane $\mathbf{2} \mathbf{b}$. The

[*] Dr. J. Beizner, Dipl-Chem. U. Dehnert

Institut für Organische Chemie der Universität

Tammannstrasse 2, D-37077 Göttingen (FRG)

Telefax: Int. code + (551)39-9475

Priv.-Doz. Dr. D. Stalke

Institut für Anorganische Chemie der Universität

Tammannstrasse 4, D-37077 Göttingen (FRG)

Telefax: Int. code + (551) 39-2582

[**] This work was supported by the Deutsche Forschungsgemeinschaft and the Fonds der Chemischen Industrie. We thank Prof. M. Rabinovitz for helpful discussions and R. Machinek, Dr. G. Elter, and W. Zolke for assistance with the NMR spectroscopic studies.
${ }^{1} \mathrm{H}$ and ${ }^{13} \mathrm{C}$ NMR spectra of $\mathbf{2 a}$ are very concentration- and temperature-dependent, and hence not very useful for structural elucidation, as they primarily contain very broad, strongly overlapping signals. The ${ }^{29} \mathrm{Si}$ NMR spectrum also exhibits two strongly broadened signals at $\delta=-26.5$ and -31.8 . Therefore, the identification of the reaction product as the 1,3-dilithiotrisilane $\mathbf{2} \mathbf{a}$ is based primarily on the results of the single-crystal $\mathrm{X}$-ray structure determination. ${ }^{[4]}$

The crystal structure of $\mathbf{2}$ a (Fig. 1) indicates that the concept of intramolecular side-chain coordination is, here too, particu-

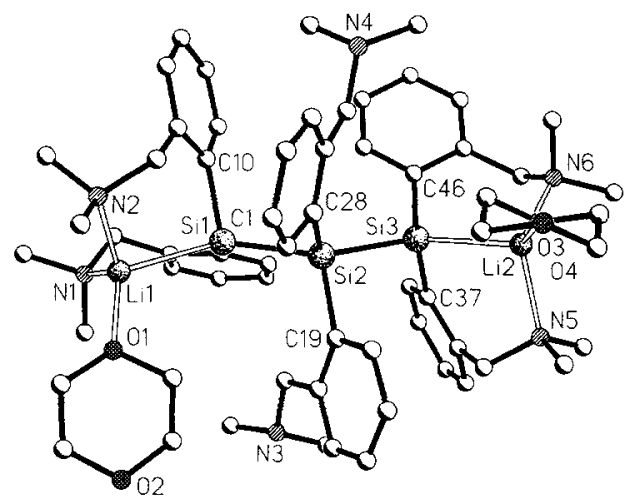

Fig. 1. Crystal structure of $\mathbf{2 a}$. Three noncoordinated dioxane molecules are omitted for clarity. Selected bond lengths [pm] and angles [ [ ${ }^{\circ}$ : Si1 -Si2 240.7(3), Si2-Si3 240.1(3), Si1 - Li1 255(1), Si3-Li2 254(1), Li1-N1 214(1), Li1-N2215(1), Li1-O1 197(1), Li2-N5 216(1), Li2-N6 211(1), Li2-O3 199(1); C1-Si1-C10 99.5(3), C19Si2-C28 101.9(3), C37-Si3-C46 99.8(3), Si1-Si2-Si3 136.9(1), Li1-Si1-Si2 131.6(3), Si2-Si3-Li2 $129.7(3)$.

larly useful-this idea has also been successfully applied to organocopper compounds ${ }^{[8]}$ and compounds containing highly coordinated silicon centers. ${ }^{[9]}$ In $\mathbf{2}$ a the lithium atoms bound to silicon are coordinated by both amino groups of the neighboring $\mathrm{Me}_{2} \mathrm{NCH}_{2} \mathrm{C}_{6} \mathrm{H}_{4}$ substituents; two chelate rings are thus formed. The average $\mathrm{Li}-\mathrm{N}$ bond length is $214 \mathrm{pm}$, significantly longer than that in contact ion pairs of lithium atoms and bases with nitrogen donors. ${ }^{[10]}$ In addition, each lithium atom is coordinated by a single oxygen atom from a dioxane molecule.

The average distance between $\mathrm{Si}$ and $\mathrm{Li}$ is significantly shorter $(254.3 \mathrm{pm})$ than in all other structurally characterized molecular compounds with $\mathrm{Si}-\mathrm{Li}$ contacts $\left(\left[\mathrm{Me}_{3} \mathrm{SiLi}\right]_{6} 265 \mathrm{pm}\right.$; $^{[11]}$ $\left.\left[\mathrm{Me}_{3} \mathrm{SiLi} \text { (tmeda }\right)_{1.5}\right] 270 \mathrm{pm},{ }^{[12]} \quad$ tmeda $=N, N, N^{\prime}, N^{\prime}$-tetramethylethylenediamine; $\left[\left(\mathrm{Me}_{3} \mathrm{Si}\right)_{3} \mathrm{SiLi}(\mathrm{dme})_{1.5}\right] 263 \mathrm{pm},{ }^{[13]}$ dme $=1,2$-dimethoxyethane; $\left[\left\{(\text { thf })_{3} \mathrm{Li}_{2}\left(\mathrm{SiPh}_{2}\right)_{4}\right] 271 \mathrm{pm} ;{ }^{[14]}\right.$ [( $\left.\left(\mathrm{Me}_{3} \mathrm{Si}\right)_{3} \mathrm{SiLi}(\mathrm{thf})_{3}\right] 264$ and $267 \mathrm{pm} ;{ }^{[15]}\left[\mathrm{Ph}_{3} \mathrm{SiLi}(\text { thf })_{3}\right]$ $\left.267 \mathrm{pm}^{[16]}\right)$. The steric demands of the six 2-( $\left(\mathrm{Me}_{2} \mathrm{NCH}_{2}\right) \mathrm{C}_{6} \mathrm{H}_{4}$ units cause a distinct stretching of the $\mathrm{LiSi}_{3} \mathrm{Li}$ backbone, which assumes an approximately antiperiplanar conformation. The bond angles along the $\mathrm{LiSi}_{3} \mathrm{Li}$ chain are significantly larger than ideal tetrahedral angles; the central $\mathrm{Si}-\mathrm{Si}-\mathrm{Si}$ angle is widened to $136.9^{\circ}$.

The reaction of 1 with excess lithium in THF yields a different product: the first 1,2-dilithiodisilane $\mathbf{3} \mathbf{a}$ is obtained in the form of deep red crystals. This compound can also be prepared by treating $\mathbf{2}$ a with lithium under the same conditions. The singlecrystal X-ray structure analysis (Fig. 2) shows that both lithium atoms are coordinated to the silicon centers, as was the case in $\mathbf{2} \mathbf{a}$.

Compound $\mathbf{3 a}$ crystallizes with two independent molecules per asymmetric unit, which only differ slightly in the orientation of the substituents (the structural parameters of the second mol- 


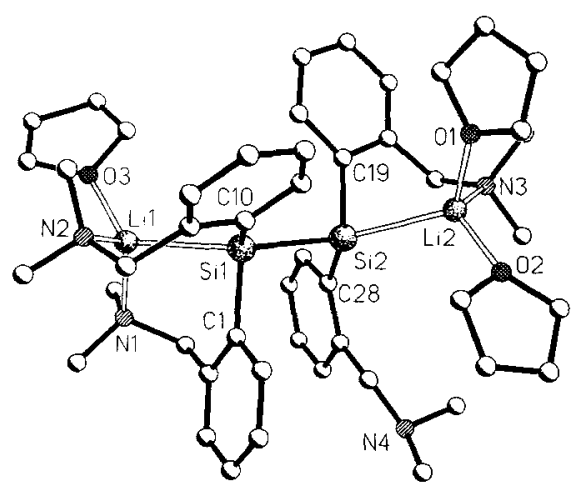

Fig. 2. Crystal structure of $\mathbf{3 a}$. Selected bond lengths [pm] and angles [']-the values separated by a slash are those for the chemically equivalent parameter in the second, crystallographically independent molecule: $\mathrm{Si} 1$ - Si2 238.0(2)/237.7(2), Si1 Li1 254.2(8)/255.0(8), Si2-Li2 258.9(8)/259.0(8), Li1-O3 195(1)/196(1), Li1-N1 217(1)/215(1), Li1-N2 213(1)/215(1), Li2-O1 198(1)/199(1), Li2-O2 196(1)/ 197(1), Li2-N3 213(1)/214(1); C1-Si1-C10 100.7(2)/99.6(2), C19-Si2-C28 102.0(2), 101.3(2), Li1-Si1-Si2 143.7(2)/143.7(2), Si1-Si2-Li2 134.9(2)/134.7(2)

ecule, not shown in the Figure, are separated from the analogous ones for the first molecule by a slash). The most striking structural feature at first glance is perhaps the different environments of the two lithium atoms: $\mathrm{Li1}$ is coordinated to two $\mathrm{Me}_{2} \mathrm{NCH}_{2}$ side chains (average $\mathrm{Li}-\mathrm{N}$ bond length 215.2/ $215.8 \mathrm{pm}$ ) and one thf molecule, while $\mathrm{Li} 2$ is surrounded by only one amino group ( $\mathrm{Li}-\mathrm{N} 212.8 / 213.7 \mathrm{pm}$ ) and two thf ligands. The two $\mathrm{Si}-\mathrm{Li}$ bond lengths are not identical (Si1 - Li1 254.2/255.0 pm, Si2-Li2 258.9/259.0 pm). Apparently, coordination to two amino side chains brings the $\mathrm{Si}$ and $\mathrm{Li}$ atoms closer together (cf., $254.3 \mathrm{pm}$ in $\mathbf{2 a}$ ). The central Si-Si bond length $(238.0 / 237.7 \mathrm{pm})$ is typical for a $\mathrm{Si}-\mathrm{Si}$ single bond and is nearly identical to that in the disilane $3 \mathbf{b}(236.4 / 238.6 \mathrm{pm}) .^{[17]}$

A side-on coordination of the lithium atoms to the central element - element bond, ${ }^{[18]}$ such has been observed for the $\mathrm{C}-\mathrm{C}$ unit in substituted dilithioethanes, is not found in $\mathbf{3 a}$. This is presumably a consequence of the intramolecular complexation.

With THF as solvent, the ${ }^{29} \mathrm{Si}$ NMR spectrum of $\mathbf{3 a}$ exhibits a $1: 1: 1: 1$ quartet at $\delta=-32.8 .^{[19]}$ The corresponding ${ }^{29} \mathrm{Si}-{ }^{7} \mathrm{Li}$ coupling constant $(36 \mathrm{~Hz})$ indicates a partially covalent character of the $\mathrm{Si}-\mathrm{Li}$ bond ${ }^{[20]}$ However, the fact that the $\mathrm{Si}-\mathrm{Li}$ bond length is shorter than in other lithiated silicon compounds is not reflected by a larger coupling constant $\left(\left[\mathrm{Me}_{2} \mathrm{PhSiLi}(\text { thf })_{x}\right] \quad 51 \mathrm{~Hz} ;{ }^{[21]} \quad\left[\mathrm{Ph}_{3} \mathrm{SiLi}(\text { thf })_{3}\right] \quad 45 \mathrm{~Hz} ;^{[16]}\right.$ $\left[\left(\mathrm{Me}_{3} \mathrm{Si}\right)_{3} \mathrm{SiLi}(\mathrm{thf})_{3}\right] 37.2 \mathrm{~Hz} ;{ }^{[1 \mathrm{~s}]}\left[\left\{(\mathrm{thf})_{3} \mathrm{Li}_{2}\left(\mathrm{SiPh}_{2}\right)_{4}\right] 32.8,40\right.$, and $42 \mathrm{~Hz}^{[14]}$ ).

These results show that the cyclotrisilane 1 is not only a valuable synthetic equivalent to silanediyls $\mathrm{Ar}_{2} \mathrm{Si},{ }^{[22]}$ its reaction with lithium also opens up access to the dilithio compounds $\mathbf{2}$ a and $\mathbf{3 a}$, which in turn should be able to function as transfer agents for $\mathrm{Si}_{3}$ and $\mathrm{Si}_{2}$ units. Studies to determine the reactivity of these compounds are currently in progress.

\section{Experimental Procedure}

All experiments were performed with exclusion of oxygen and moisture. Where possible, the assignments of ${ }^{1} \mathrm{H},{ }^{13} \mathrm{C}$, and ${ }^{29} \mathrm{Si}$ NMR signals to atoms of the terminal or central diaryldisilanediyl units in $\mathbf{2 a}$ and $\mathbf{2} \mathbf{b}$ are indicated by the numbers $(1,3)$ or (2), respectively, after the element symbol. The ${ }^{7} \mathrm{Li}$ NMR spectra were calibrated externally with $\mathrm{LiCl} / \mathrm{H}_{2} \mathrm{O}$.

2a: Lithium shavings ( $31 \mathrm{mg}, 4.47 \mathrm{mmol}$ ) were added to a solution of $1(1.99 \mathrm{~g}$, $2.24 \mathrm{mmol})$ in dioxane $(28 \mathrm{~mL})$. The resulting mixture was stirred for $22 \mathrm{~h}$ at $25^{\circ} \mathrm{C}$. The volume of the clear red solution was reduced by about $2 / 3$, and hexane $(8 \mathrm{~mL})$ added. Residual lithium was then removed by filtration. Crystallization at $4^{\circ} \mathrm{C}$ yielded $2 \mathrm{a}$ as bright red crystals $\left(1.18 \mathrm{~g}, 49 \%\right.$ yield, m.p. $50-60^{\circ} \mathrm{C}$ (decomp.)), which still contained 2 equiv of dioxane per molecule of 2 a after solvent remova under high vacuum. ${ }^{1} \mathrm{H}$ NMR $\left(250 \mathrm{MHz},\left[\mathrm{D}_{8}\right] \mathrm{THF}, 25^{\circ} \mathrm{C}\right): \delta=1.35$ (brs, $12 \mathrm{H}$; $\mathrm{NMe}_{2}$ ), 1.93 (s, 24 H; $\mathrm{NMe}_{2}$ ), 2.3-3.4 (brs, 8H; $\mathrm{CH}_{2}$ ), 3.6-4.1 (brs, $4 \mathrm{H}_{;} \mathrm{CH}_{2}$ ), $6.4-6.9$ (brs, $10 \mathrm{H}), 6.91\left(\mathrm{t},{ }^{3} J=7.5 \mathrm{~Hz}, 4 \mathrm{H}\right), 7.18\left(\mathrm{~d},{ }^{3} J=7.2 \mathrm{~Hz}, 4 \mathrm{H}\right), 7.6-8.1$ (brs, $4 \mathrm{H} ; 6-\mathrm{H}(1,3)$ ), 8.6-8.9 (brs, $2 \mathrm{H} ; 3-\mathrm{H}(2)$ ); ${ }^{7} \mathrm{LiNMR}$ (155.45 MHz. THF! $\left.\mathrm{C}_{6} \mathrm{D}_{6}(5: 1), 25^{\circ} \mathrm{C}\right): \delta=0.90$ (s); ${ }^{29} \mathrm{Si} \mathrm{NMR}\left(99.3 \mathrm{MHz},\left[\mathrm{D}_{8}\right] \mathrm{THF}, 25^{\circ} \mathrm{C}\right)$ : $\delta=-26.5(\mathrm{Si}-2),-31.8(\mathrm{Si}-1,3)$

2b: A solution of $2 \mathbf{a}(1.05 \mathrm{~g} .0 .93 \mathrm{mmol})$, which still contained 2.5 equiv of dioxane, in THF $(10 \mathrm{~mL})$ was cooled to $-78^{\circ} \mathrm{C}$ and treated with cyclopentadiene $(0.19 \mathrm{~mL}$. $2.33 \mathrm{mmol}$ ). The mixture was stirred and allowed to warm to room temperature. The solvent was removed, hexane $(15 \mathrm{~mL})$ was added, and undissolved components were removed by filtration. Volume reduction of the filtrate yielded $\mathbf{2} \mathbf{b}$ as hydrolysis-sensitive crystals $\left(0.56 \mathrm{~g}, 68 \%\right.$ yield, m.p. $\left.171-172^{\circ} \mathrm{C}\right) .{ }^{1} \mathrm{H}$ NMR $(250 \mathrm{MHz}$, $\left.\mathrm{C}_{6} \mathrm{D}_{6}\right): \hat{\partial}=1.79\left(\mathrm{~s}, 12 \mathrm{H} ; \mathrm{NMe}_{2}\right), 2.00\left(\mathrm{~s}, 24 \mathrm{H} ; \mathrm{NMe}_{2}\right), 3.04\left(\mathrm{~s}, 4 \mathrm{H} ; \mathrm{CH}_{2}\right), 3.25 .3 .27$ (AB system, $\left.{ }^{2} J=14 \mathrm{~Hz}, 8 \mathrm{H} ; \mathrm{CH}_{2}\right), 5.87\left(\mathrm{~s},{ }^{1} J(\mathrm{Si}, \mathrm{H})=200.5 \mathrm{~Hz}, 2 \mathrm{H} ; \mathrm{SiH}\right), 6.92$ $\left(\mathrm{dd},{ }^{3} J(4,5)=7.5 \mathrm{~Hz},{ }^{3} J(5,6)=7.2 \mathrm{~Hz}, 4 \mathrm{H} ; 5-\mathrm{H}(1,3)\right), 7.09\left(\mathrm{dd},{ }^{3} J(3,4)=7.4 \mathrm{~Hz}\right.$, $\left.{ }^{3} J(4,5)=7.5 \mathrm{~Hz}, 4 \mathrm{H} ; 4-\mathrm{H}(1,3)\right), 7.22\left(\mathrm{dd},{ }^{3} J(4,5)=7.5 \mathrm{~Hz},{ }^{3} J(5,6)=7.2 \mathrm{~Hz}, 2 \mathrm{H}\right.$; $5-\mathrm{H}(2)), 7.33\left(\mathrm{dd},{ }^{3} J(3,4)=7.6 \mathrm{~Hz},{ }^{3} J(4,5)=7.5 \mathrm{~Hz}, 2 \mathrm{H} ; 4-\mathrm{H}(2)\right), 7.36(\mathrm{~d}$, $\left.{ }^{3} J(3,4)=7.4 \mathrm{~Hz}, 4 \mathrm{H} ; 3-\mathrm{H}(1,3)\right), 7.71\left(\mathrm{~d},{ }^{3} J(5,6)=7.2 \mathrm{~Hz}, 4 \mathrm{H} ; 6-\mathrm{H}(1.3)\right), 7.81(\mathrm{~d}$, $\left.{ }^{3} J(3,4)=7.6 \mathrm{~Hz}, 2 \mathrm{H} ; 3-\mathrm{H}(2)\right), 8.60\left(\mathrm{~d},{ }^{3} J(5.6)=7.2 \mathrm{~Hz}, 2 \mathrm{H} ; 6-\mathrm{H}(2)\right):{ }^{13} \mathrm{C}$ NMR $\left(62.9 \mathrm{MHz}, \mathrm{C}_{6} \mathrm{D}_{6}\right): \delta=45.15,45.28\left(2 \times \mathrm{NMe}_{2}\right), 63.99,64.46\left(2 \times \mathrm{CH}_{2}\right), 125.98$, $128.22,128.98,129.05,129.50,(5 \times \mathrm{CH}), 135.54,135.74(\mathrm{C}-1(1,2.3)), 138.43 .138 .72$ $(\mathrm{C}-6(1,2,3)), 146.04(\mathrm{C}-2(1,3)), 148.07(\mathrm{C}-2(2)):{ }^{29} \mathrm{Si}$ NMR $\left(59.6 \mathrm{MHz}, \mathrm{C}_{6} \mathrm{D}_{6}\right)$ $\delta=-37.5$ (brs), $-43.9\left(\mathrm{~d},{ }^{1} J(\mathrm{Si}, \mathrm{H})=203 \mathrm{~Hz}\right) ; \mathrm{MS}(70 \mathrm{eV}) \mathrm{m} / z(\%): 890\left(\mathrm{M}^{4}\right.$ $<1 \%), 297\left(\mathrm{Ar}_{2} \mathrm{SiH}^{+}, 100\right)$.

3a: Lithium shavings $(45 \mathrm{mg}, 7.38 \mathrm{mmol})$ were added to a solution of $1(1.09 \mathrm{~g}$, $1.23 \mathrm{mmol})$ in THF $(18 \mathrm{~mL})$. The resulting mixture was stirred for $3 \mathrm{~d}$ at $25^{\circ} \mathrm{C}$ Residual lithium was removed from the clear, deep red solution by filtration, the solution volume was reduced (to ca. $3 \mathrm{~mL}$ ), and pentane $(10 \mathrm{~mL}$ ) was added. Crystallization at $-15^{\circ} \mathrm{C}$ yielded $3 \mathrm{a}$ in the form of dark red crystals, which contained 4 equiv of THF per molecule of $3 \mathrm{a}\left(0.87 \mathrm{~g}, 53 \%\right.$ yield, m.p. $45-50{ }^{\circ} \mathrm{C}$ (decomp.)). ${ }^{1} \mathrm{H}$ NMR (250 MHz, $\left.\mathrm{C}_{6} \mathrm{D}_{6}\right): \delta=1.82$ (br s. $24 \mathrm{H} ; \mathrm{NMe}_{2}$ ), 2.7-3.4 (brs, $8 \mathrm{H} ; \mathrm{CH}_{2}$ ), $6.8-7.1(\mathrm{~m}, 4 \mathrm{H} ; 3-\mathrm{H}), 7.0-7.3(\mathrm{~m}, 8 \mathrm{H} ; 4.5-\mathrm{H}), 8.36($ br s, $4 \mathrm{H} ; 6-\mathrm{H}):{ }^{13} \mathrm{C}$ NMR $\left(75.5 \mathrm{MHz}, \mathrm{C}_{6} \mathrm{D}_{6}\right) ; \delta=46.14\left(\mathrm{NMe}_{2}\right), 67.71\left(\mathrm{CH}_{2}\right), 122.44,126.08(\mathrm{C}-4.5), 130.23$ (C-3), 139.12 (C-6), 142.48 (C-2), 162.20 (C-1); ${ }^{7} \mathrm{Li} \mathrm{NMR}\left(155.45 \mathrm{MHz}, \mathrm{C}_{6} \mathrm{D}_{6}\right)$ : $\delta=1.36$ (s); ${ }^{29} \mathrm{Si} N \mathrm{NMR} \quad\left(59.6 \mathrm{MHz}, \quad \mathrm{THF} / \mathrm{C}_{6} \mathrm{D}_{6} \quad(5: 1), \quad 25^{\circ} \mathrm{C}\right) ; \quad \delta=-32.8$ $\left({ }^{1} J(\mathrm{Si}, \mathrm{Li})=36 \mathrm{~Hz}\right)$.

Received: August 9, 1994 [Z 7224 IE] German version: Angew. Chem. 1994, 106, 2580

[1] A. G. Brook, H. Gilman, J. Am. Chem. Soc. 1954, 76, 278-279; b) H. Gilman. G. D. Lichtenwalter, ibid. 1958, 80,608-611.

[2] B. Kirste, R. West. H. Kurreck, J. Am. Chem. Soc. 1985, 107. 3013-3016.

[3] a) H. Gilman, D. J. Peterson, A. W. Jarvie, H. J. S. Winkler, J. Am. Chem. Soc. $1960,82,2076$; b) H. Gilman, G. L. Schwebke, ibid. 1963, 85, 1016; c) E Hengge, D. Wolfer, J. Organomet. Chem. 1974, 66, 413-424.

[4] Crystal structure data for 2a: $\mathrm{Ar}_{6} \mathrm{Si}_{3} \mathrm{Li}_{2}$ (dioxane) ${ }_{2}+3$ dioxane $(\mathrm{Ar}=2$. $\left.\left(\mathrm{Me}_{2} \mathrm{NCH}_{2}\right) \mathrm{C}_{6} \mathrm{H}_{4}\right), M=1424.05$, triclínic, space group $P \overline{1}, a=1442.6(3)$, $b=1633.1(3), c=2025.1(4) \mathrm{pm}, x=66.87(3), \beta=79.54(3), \gamma=69.96(3)^{\prime \prime}$ $V=4.116(2) \mathrm{nm}^{3}, Z=2, \rho_{\text {calcd }}=1.149 \mathrm{~g} \mathrm{~cm}^{-3}, F(000)=1548, \lambda=71.073 \mathrm{pm}$, $T=-120^{\circ} \mathrm{C}, \mu\left(\mathrm{Mo}_{K_{x}}\right)=0.113 \mathrm{~mm}^{-1}$, crystal dimensions: $0.6 \times 0.4 \times 0.4 \mathrm{~mm}$, $8^{\circ} \leq 2 \theta \leq 45^{\circ}$; total number of reflections 12625 , of which 10698 were independent; all of these were used to refine 952 parameters, with 212 restraints for the 1-2 and 1-3 distances in the coordinated and noncoordinated dioxane molecules; maximum residual electron density: $581 \mathrm{enm}^{-3}, R 1 \quad(F>4 \sigma(F))=$ $0.057, \quad w R 2=0.161 \quad$ (all data) $\left(R 1=\sum|| F_{\mathrm{o}}|-| F_{\mathrm{c}}|| / \sum\left|F_{\mathrm{v}}\right|, \quad w R 2=\right.$ $\left(\sum w\left(F_{\mathrm{o}}^{2}-F_{\mathrm{c}}^{2}\right)^{2} / \sum w\left(F_{\mathrm{o}}^{2}\right)^{2}\right)^{0.5}$. Crystal structure data for $\mathbf{3 a}: \mathrm{Ar}_{4} \mathrm{Si}_{2} \mathrm{Li}_{2}(\operatorname{thf})_{3}$ $\left(\mathrm{Ar}=2-\left(\mathrm{Me}_{2} \mathrm{NCH}_{2}\right) \mathrm{C}_{6} \mathrm{H}_{4}\right), \quad M=823.16$, triclinic, space group $P \overline{1}, a=$ $1052.5(2), \quad b=2155.3(4), \quad c=2376.2(5) \mathrm{pm}, \quad x=66.26(3), \quad \beta=89.48(3)$, $\gamma=88.30(3)^{\circ}, V=4.932(2) \mathrm{nm}^{3}, Z=4, \rho_{\text {calcd }}=1.109 \mathrm{~g} \mathrm{~cm}^{-3} . F(000)=1784$. $\lambda=71.073 \mathrm{pm}, T=-120^{\circ} \mathrm{C}, \mu\left(\mathrm{Mo}_{\mathrm{K} x}\right)=0.113 \mathrm{~mm}^{-1}$. crystal dimensions: $0.7 \times 0.6 \times 0.6 \mathrm{~mm}, 4^{\circ} \leq 2 \theta \leq 45^{\circ}$; total number of reflections 12732 , of which 12663 were independent; all of these were used to refine 1099 parameters; maximum residual electron density: $470 \mathrm{enm}^{-3}, R 1 \quad(F>4 \sigma(F))=0.080$, $w R 2=0.242$ (all data). The data for both structures were collected on a StoeAED diffractometer. The intensity measurements were collected, by the $2 \theta / 0$ method, with crystals that were shock-cooled in a drop of oil [5]. The structures were solved by direct methods (SHELXS-90) [6] and refined by the leastsquares method vs $F^{2}$ [7]. Further details of the crystal structure investigations are available on request from the Cambridge Crystallographic Data Centre, 12 Union Road, GB-Cambridge, CB2 1EZ, on quoting the full journal citation.

[5] T. Kottke, D. Stalke, J. Appl. Crystallogr. 1993, 26, 615-619.

[6] G. M. Sheldrick, Acta Crystallogr. Sect. A 1990, 46, 467-473.

[7] G. M. Sheldrick, SHELXL-93, program for the refinement of crystal structures, Göttingen, 1993.

[8] a) G. van Koten, J. G. Noltes in Compehensive Organometallic Chemistry (Eds.: G. Wilkinson. F. G. A. Stone, E. W. Abel), Pergamon Press, Oxford, 1982, pp. 709-763; b) G. van Koten, J. Organomet, Chem. 1990, 400. 283 -301.

[9] a) R. J. P. Corriu, C. Guerin, Adv. Organomet. Chem. 1982, 20, 265-312; b) C. Chuit, R. J. P. Corriu, C. Reye, J. C. Young, Chem. Rev. 1993, 93, 1371-1448. 
[10] a) K. Gregory, P, von R. Schleyer, R. Snaith, Ady. Inorg. Chem. 1991, 37 47-142; b) H. Gornitzka, D. Stalke, Organometallics, in press; c) U. Olsher R. M. Izatt. J. S. Bradshaw, N. K. Dalley, Chem. Rev. 1991. 91, 137-164.

[11] a) T. F. Schaaf, W. Butler, M. D. Glick, J. P. Oliver, J. Am. Chem. Soc. 1974, 96 $7593-7594$ : b) W. H. Ilsley. T. F. Schaaf. M. D. Glick. J. P. Oliver. ibid. 1980, $102.3769-3774$.

[12] B. Teclé, W. H. Ilsley, J. P. Oliver, Organometallics 1982, $1,875877$.

[13] G. Becker. H.-M. Hartmann, A. Münch, H. Riffel, Z. Anorg. Allg. Chem. 1985 $530.29 \quad 42$.

[14] G. Becker, H.-M. Hartmann, E. Hengge, F. Schrank, Z. Anorg. Allg. Chem $1989,572,63-74$

[15] A. Heine, R. Herbst-lrmer, G. M. Sheldrick. D. Stalke, Inorg. Chrm. 1993. 32 2694- 2698.

[16] H. V. R. Dias. M. M. Olmstead, K. Ruhlandt-Senge, P. P. Power, $f$ Organomet. Chem. 1993, 462,1-6.

[17] J. Belzner. N. Detomi. H. Ihmels. M. Noltemeyer, Angew. Chem. 1994, 106 1949 1950; Anges: Chem. Int. Ed. Engl. 1994, 33, 1854-1855.

[18] a) M. Walczak. G. D. Stucky. f. Organomet. Chem. 1975, 97, 313-323; b) M Walczak, G. Stucky. J. Am. Chem. Soc. 1976, 98, $5531-5539$; c) A. Sekiguchi, T. Nakanishi, C. Kabuto, H. Sakurai, ibid. 1989, 111. 3748-3750; d) Chem. Lett. 1992, 867-870.

[19] Experiments to observe the different environments of the $\mathrm{Li}$ atoms, which were found in the crystal 3 a. by NMR spectroscopy were not successful, even in such poorly coordinating solvents as $\left[\mathrm{D}_{8}\right]$ toluene or $\mathrm{C}_{6} \mathrm{H}_{6}$

[20] C. Lambert, P. von R. Schleyer, Angew. Chem. 1994, 106. 1187-1199; Angew Chem. Int. Ed. Engl. 1994, 33, 1129-1140.

[21] U. Edlund. T. Lejon, T. K. Venkatachalam, E. Buncel, J. Am Chem. Soc 1985 107. 6408-6409.

[22] See. for example. J. Belzner, H. Ihmels, Tetrahedron Lett. 1993,34, 6541-6544.

\section{A Chiral Lewis Acid with Two "Metal" Centers: Cooperative Binding of Two Amine Molecules to a Chiral Diboronic Ester**}

Kyoko Nozaki, Masanori Yoshida, and Hidemasa Takaya*

Lewis acid/Lewis base interactions are one of the most fundamental types of binding in organic chemistry. Although asymmetric reactions with chiral Lewis acid catalysts are well studied, ${ }^{[1]}$ only a few reports have focused on structural aspects of the interaction of Lewis acids and Lewis bases. ${ }^{[2]}$ Here, we describe the design and synthesis of a chiral Lewis acid having two "metal" centers, ${ }^{[3]}$ ortho-bis[(4R,5R)-4,5-diphenyl-1,3-dioxa-2borolane-2-yllbenzene (1a). This compound contains two dioxaborolane units that can bind two amine molecules cooperatively. ${ }^{[4,5]}$

The chiral ortho-diboronate 1 a was synthesized along with the meta isomer $\mathbf{1 b}$, para isomer $\mathbf{1} \mathbf{c}$, and analogue $\mathbf{2}$, which contains one Lewis-acidic center, and their binding properties with amines were examined. The interaction of ortho-diboronate $1 \mathrm{a}$ with benzylamine is unique, as evident in ${ }^{1} \mathrm{HNMR}$ spectra. Thus a mixture of $\mathbf{1}$ a and benzylamine exhibited the following three notable features: 1) The two originally enantiotopic benzylic protons of the amine appear as a quartet with an $A B$ pattern typical for diastereotopic protons. 2) The signals

$\left[{ }^{*}\right]$ Prof. Dr. H. Takaya, M. Yoshida, Dr. K. Nozaki

Division of Material Chemistry. Graduate School of Engineering

Kyoto University, Sakyo-ku, Kyoto, 606-01 (Japan)

Telefax: Int. code $+(75) 761-8846$

$\left[{ }^{* *}\right]$ This work was supported by a Grant-in-Aid for Developmental Scientific Research (No. 06555272) and by a Grant-in-Aid for Scientific Research (No. 06750885: fellowship for K. N.) both from the Ministry of Education. Science and Culture, Japan. K. N. also thanks The Asahi Glass Foundation for partial financial support. arising from the $\mathrm{NH}$ protons are shifted markedly downfield relative to those of the free benzylamine. 3) The signal due to the methine protons of the dioxaborolane units of 1 a remains a singlet and is only shifted slightly upfield. These results indicate that the amine is complexed with diboronate $\mathbf{1} \mathbf{a}$ and influenced by the chiral surroundings. Since the equilibrium for the formation of the complex at $20^{\circ} \mathrm{C}$ is rapid on the NMR timescale, the observed signal of the methine protons in $\mathbf{1} \mathbf{a}$ is a singlet. In sharp contrast to the ortho-diboronate $1 \mathbf{a}$, meta- and para-diboronates, $\mathbf{1} \mathbf{b}$ and $\mathbf{1} \mathbf{c}$, and monoboronate $\mathbf{2}$ show only small changes in their NMR spectra upon mixture with benzylamine under the same conditions, and the benzylic protons of the amine give rise to a singlet. ${ }^{[6]}$ The exceptionally strong binding of 1 a with benzylamine has been demonstrated by titrations of boronates $\mathbf{1} \mathbf{a}, \mathbf{1} \mathbf{b}, \mathbf{1} \mathbf{c}$, and $\mathbf{2}$ with the amine (Fig. 1). Titrations of the ortho-diboronate 1 a show a characteristic marked saturation effect.<smiles>c1ccc(B2O[C@@H](c3ccccc3)[C@H](c3ccccc3)O2)cc1</smiles>

a: ortho1b: meta1c: para-<smiles>c1ccc(B2OC(c3ccccc3)C(c3ccccc3)O2)cc1</smiles>

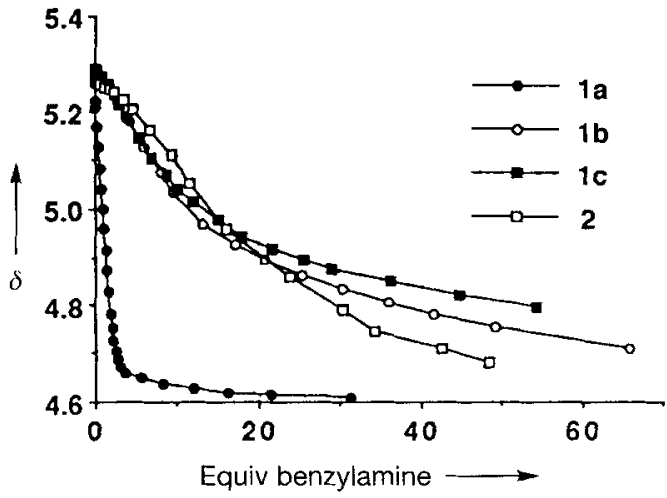

Fig. 1. Titration of boronates $1 \mathrm{a}-\mathrm{c}$ and 2 with benzylamine at $20^{\circ} \mathrm{C}(0.10 \mathrm{M}$ of $1 \mathrm{a}-\mathrm{c}$ or 2 in $\mathrm{CDCl}_{3}$ ). Chemical shifts of the singlets due to the methine protons of the boronates (around $\delta=5.3$ ) are plotted against the molar equivalents of added benzylamine.

The complexation ratio of $\mathbf{1} \mathbf{a}$ : benzylamine $=1: 2$ was determined with a Job plot ${ }^{[7]}$ based on ${ }^{1} \mathrm{H}$ NMR spectroscopic data (conditions: $T=20^{\circ} \mathrm{C},[1 \mathrm{a}]_{\text {initial }}+[\text { amine }]_{\text {initial }}=0.05 \mathrm{M}$ in CD$\mathrm{Cl}_{3}$ ). Maximum complex formation occurred at $[\mathbf{1} \mathbf{a}]_{\text {initial }} /$ $\left([\mathbf{1}]_{\text {initial }}+[\text { amine }]_{\text {initial }}\right)=0.33$. Accordingly, the complexation equilibrium of 1 a with benzylamine can be described by Equations (a) and (b). Benesi-Hildebrand analysis ${ }^{[8]}$ indicates that

$$
\begin{aligned}
& \mathbf{1} \mathbf{a}+(\text { amine }) \stackrel{K_{1}}{\rightleftarrows} \mathbf{1 a} \cdot \text { (amine) } \\
& \mathbf{1 a} \cdot(\text { amine })+(\text { amine }) \stackrel{K_{2}}{\longleftarrow} \mathbf{1 a} \cdot(\text { amine })_{2}
\end{aligned}
$$

the binding of the second amine molecule to diboronate $\mathbf{1}$ a is remarkably enhanced compared to that of the first amine molecule $\left(K_{2} \gg K_{1}\right)$. The plot of $1 /[\text { amine }]_{\text {initial }}^{2}$ vs $1 / \Delta \delta_{\text {observed }}$ shows good linearity in the region where $[\text { amine }]_{\text {initial }}>$ $10 \times[\mathbf{1} a]_{\text {initial }}\left([\mathbf{1} \mathbf{a}]_{\text {initial }}=0.10 \mathrm{M}\right)$. This indicates that the contri- 